\title{
, \\ Impact of Rotational Sequence Selection on Weed Seedbank Composition in Australian Broadacre Crops
}

\author{
Saliya Gurusinghe (D), K. M. Shamsul Haque, Paul A. Weston (D), William B. Brown and Leslie A. Weston *(i) \\ Graham Centre for Agricultural Innovation, NSW Department of Primary Industries and Charles Sturt University, \\ Wagga Wagga, NSW 2678, Australia; sgurusinghe@csu.edu.au (S.G.); khaque@csu.edu.au (K.M.S.H.); \\ pweston@csu.edu.au (P.A.W.); plantinteractions@csu.edu.au (W.B.B.) \\ * Correspondence: leweston@csu.edu.au
}

Citation: Gurusinghe, S.; Haque, K.M.S.; Weston, P.A.; Brown, W.B.; Weston, L.A. Impact of Rotational Sequence Selection on Weed Seedbank Composition in Australian Broadacre Crops. Agronomy 2022, 12, 375. https://doi.org/10.3390/ agronomy12020375

Academic Editor: Anestis Karkanis

Received: 24 December 2021

Accepted: 31 January 2022

Published: 1 February 2022

Publisher's Note: MDPI stays neutral with regard to jurisdictional claims in published maps and institutional affiliations.

Copyright: (c) 2022 by the authors. Licensee MDPI, Basel, Switzerland. This article is an open access article distributed under the terms and conditions of the Creative Commons Attribution (CC BY) license (https:// creativecommons.org/licenses/by/ $4.0 /)$.

\begin{abstract}
The use of competitive crops in successional rotations has been shown to reduce the growth and establishment of annual weeds by the depletion of the weed seedbank in broadacre cropping systems. However, the impact of specific crop rotational sequences contributing to weed seedbank density has not been quantified in the Riverina region of southern Australia. Trials were established in two locations in 2014-2018 to quantify the impact of selected annual rotations featuring grain, pulse, and pasture crops on weed infestation and seedbank dynamics with a focus on winter and summer annual weeds. The weed seedbank dynamics were evaluated by a twice-annual soil sampling regime (at planting and harvest), followed by soil sample screening for weed propagule germination and seedling establishment in a subsequent controlled-environment screening performed from 2014-2020. The weed seedling density decreased in the cereal rotations in years experiencing average to above-average rainfall, as crops established a dense canopy leading to reduced weed establishment and fecundity. Several rotational treatments were effective in suppressing the weed propagule numbers over time, including those using dual-purpose cereals only or a canola break-crop along with the cereals. Rotational selection can be an important and cost-effective tool in integrated weed management systems when applied over multiple growing seasons.
\end{abstract}

Keywords: agronomic weeds; crop competition; rotational cereal crops; seedbank; weed suppression

\section{Introduction}

The Riverina and Central West regions of New South Wales form part of the Eastern grain belt of Australia [1] with major broadacre crops including wheat, barley, triticale, oats, and canola accounting for at least a quarter of the total Australian grain output estimated at $\sim \$ 3.1$ billion in 2020 [2]. The continuous cropping of cereals in this region has resulted in detrimental impacts on soil health and significantly reduced productivity in recent years. This decline has been associated with the increased prevalence of crop pests and diseases [3], reduced efficiency in nutrient uptake and utilization [4,5], and increased selection pressure for the establishment of certain annual weeds, particularly problematic annual grasses [6,7]. With weed management costs to Australian grain producers exceeding $\$ 3$ billion annually, advancements in cost-effective and easily adoptable weed management strategies are needed.

The shift to conservation tillage cropping in Australia has resulted in significant crop residue retention on the soil surface in much of grain production acreage across the Riverina; this practice has also been facilitated using highly effective pre- and postemergent herbicides [8]. Consequently, the development of annual ryegrass resistance to multiple herbicide families, including that of glyphosate, has proven to be a major problem facing Australian producers $[9,10]$. Resistant annual ryegrass can be exceptionally difficult to control, and its management has direct ramifications for the successful production of cereal crops, particularly in Western Australia and New South Wales [11]. Annual 
ryegrass is typically managed in Australian cereal crops using multiple cultural practices including chemical control, early sowing, higher seeding density, timely post-harvest grazing, and occasional tillage [11], plus the strategic use of competitive crops and pasture species [12-14], and most recently, by the reduction of viable seeds through harvest weed seed destruction using chaff-lining [15] and weed seed destructors [16].

Competitive crops can also provide a cost-effective means of weed suppression by competing with annual weeds for resources including space, photosynthetically active solar radiation, water, and nutrients [17]. In addition, chemical interference mediated by the production and release of phytotoxic secondary plant metabolites in decomposing plant residues, or root exudation of such metabolites into the soil rhizosphere, may also contribute to reduced weed establishment [18]. The development of crop cultivars and their residues with enhanced ability to interfere with weed growth allows for cost-effective control with respect to the management of difficult-to-control weeds [13,19-21].

Diversified and/or specifically timed crop rotations are known to provide distinct advantages for producers with respect to the management of annual weeds. The inclusion of broadleaf rotational crops such as canola, lupins, or pasture legumes can improve the control of gramineous weeds by allowing for improved crop competition while also making available a broad range of selective herbicides for in-crop use, particularly useful under no-till conditions [22]. The incorporation of an annual pasture phase in a long-term cereal rotational sequence may also reduce the emergence and establishment of certain annual weeds [14]. Longer crop rotations using diverse annual and perennial legume species have recently been shown to reduce the emergence and fecundity of weeds. For example, the use of subterranean clover reduced annual ryegrass density by up to $45 \%$, in contrast to other legumes such as bladder clover [23]. Kleemann et al. [24] found that a crop rotation including oats, field pea, wheat, and barley depleted the annual weed seedbank by $87 \%$ at the end of a four-year cropping sequence in southern Australia, particularly when integrated with an effective herbicide strategy.

Other crop-rotational studies highlight the legacy effects of the use of effective weed suppressive crop rotational sequences spanning a decade $[25,26]$. These studies assessed aboveground weed emergence, growth, and fecundity. However, examination of the weed seedbank following long term rotational sequences could provide unique insights into the selectivity, abundance, and diversity of annual weeds, which in turn, are legacies of an effective crop management strategy [27]. However, the impact of longer crop rotational sequences on the weed seedbank and species diversity has not been previously assessed in longer-term studies performed in southeastern Australian mixed farming systems.

Therefore, the aim of this study was to evaluate the impact of crop rotational selection on weed seedbank dynamics in this region using replicated experiments performed over five growing seasons in two locations varying in climate and rainfall, as is typical of the region. Cereal and dual-purpose crops and pulses, as well as annual and perennial pastures, were included in the evaluated rotational sequences. We hypothesized that competitive cereal-dominated rotations could reduce the weed seedbank in both locations. Controlled-environment experiments were subsequently conducted to assess the suitability of selected rotational cropping sequences in each season over a five-year period. Our findings may contribute to more sustainable crop production systems and the development of cost-effective weed management systems, particularly in the presence of herbicideresistant weeds.

\section{Materials and Methods}

\subsection{Site Characteristics}

Field experiments were conducted from 2014 through 2018 at the Charles Sturt University (CSU) Graham Centre experimental farm in Wagga Wagga $\left(35^{\circ} 02^{\prime} 00.5^{\prime \prime} \mathrm{S}\right.$ $\left.147^{\circ} 21^{\prime} 40.6^{\prime \prime} \mathrm{E}\right)$, and the NSW Department of Primary Industries farm in Condobolin $\left(33^{\circ} 03^{\prime} 44.1^{\prime \prime} \mathrm{S} 147^{\circ} 14^{\prime} 11.8^{\prime \prime} \mathrm{E}\right)$, New South Wales, Australia. Wagga Wagga receives an average of $571.5 \mathrm{~mm}$ of rainfall annually, with a minimum temperature of $9{ }^{\circ} \mathrm{C}$ and a maximum 
of $22.2{ }^{\circ} \mathrm{C}$. In comparison, Condobolin receives a lower average rainfall $(457 \mathrm{~mm})$, with minimum and maximum average temperature of 10.2 and $24.6^{\circ} \mathrm{C}$, respectively. Soils at both sites were characterized as a red kandosol and a sodosol, respectively.

\subsection{Establishment of Field Trials and Crop Harvest}

Experimental fields were sown in Wagga Wagga on April 25, May 2, May 14, May 20, and May 17th, respectively, in 2014-2018, while fields at the Condobolin site were only established on May 15, May 20, and May 11 in 2015-2017. Unfortunately, significant field-flooding events during the 2017-2018 growing season reduced the trial duration to 3.5 years in Condobolin. No flooding was experienced during this period in Wagga Wagga. Rotational grazing management treatments in this mixed farming (focused on broadacre crop and livestock production) region consisted of crops including grain and dual-purpose (grain crop with potential for grazing) wheat, grazing barley, grazing oats, both grain and dual-purpose canola (oilseed rape), field peas, a subterranean clover/phalaris pasture mix, and a perennial lucerne pasture (Table 1). Treatment fields designated as "grazing" were mowed at a height of $30 \mathrm{~cm}$ once (just prior to stem elongation for cereals and just prior to bud elongation for canola) during production to simulate grazing. Similarly, the lucerne treatment field was mowed once, according to biomass production, during the winter growing season. With the exception of the perennial lucerne and annual pasture mixture treatment fields, which were retained, all other crop rotational sequences were rotated on a yearly basis. All rotational crops were seeded at recommended sowing rates at each location based on average yearly rainfall and climatic conditions experienced.

Table 1. Standard crop and pasture rotational species selected for field experimentation in the Riverina region of southern Australia at Wagga Wagga and Condobolin NSW.

\begin{tabular}{|c|c|c|c|c|}
\hline Crop/pasture & Cultivar & Scientific name & Description & $\begin{array}{c}\text { Identification } \\
\text { key }\end{array}$ \\
\hline \multirow{2}{*}{ Wheat } & Suntop & Triticum aestivum & Grain & W \\
\hline & Wedgetail & L. & Dual-purpose & GW \\
\hline \multirow{2}{*}{ Barley } & Hindmarsh & Hordeum vulgare & Grain & B \\
\hline & Urambie & L. & Dual-purpose & GB \\
\hline Oats & Echidna & Avena sativa $\mathrm{L}$. & Dual-purpose & GO \\
\hline Triticale & Endeavour & $\begin{array}{l}\times \text { Triticosecale } \\
\text { Wittmack }\end{array}$ & Dual-purpose & GT \\
\hline Canola & $\begin{array}{l}\text { GT-50 } \\
\text { 971-CL }\end{array}$ & Brassica napus L. & $\begin{array}{c}\text { Grain } \\
\text { Dual- purpose }\end{array}$ & $\begin{array}{c}\mathrm{C} \\
\mathrm{GC}\end{array}$ \\
\hline Lucerne & SARDI & $\begin{array}{c}\text { Medicago sativa } \\
\text { L. }\end{array}$ & Grazing & $\mathrm{L}$ \\
\hline Field pea & Twilight & Pisum satioum L. & Seed & $\mathrm{P}$ \\
\hline Faba bean & IMI-3 & Vicia faba L. & Seed & $\mathrm{F}$ \\
\hline Phalaris / & Holdfast/ & $\begin{array}{c}\text { Phalaris aquatic } \\
\text { L. }\end{array}$ & Grazing & \\
\hline $\begin{array}{l}\text { Subterranean } \\
\text { clover }\end{array}$ & Mintaro & $\begin{array}{c}\text { Trifolium } \\
\text { subterraneum L. }\end{array}$ & Grazing & PM \\
\hline
\end{tabular}

Standard cultural practices were applied in all locations and years and included the application of a pre-emergence herbicide (trifluralin; TriflurX, Nufarm, Laverton North, VIC, Australia) prior to the planting of cereal crops and the pre-seeding application of inoculants for the legume species. DAP fertilizer was applied at a rate of $100 \mathrm{~kg} \mathrm{ha}^{-1}$ in all cereal crops, and insecticide was applied pre-sowing to canola plots, if warranted. Due to higher rainfall, fungicide and nitrogen top-dressing were applied only at the Wagga Wagga field site, as required. In both trial locations, plots ( $12.6 \mathrm{~m}$ long, $1.6 \mathrm{~m}$ wide) were established using a randomized complete block design with four replications. Forage crops were established in rotations and managed with mowing as needed to simulate a once-yearly grazing event by livestock on selected grazing cereal cultivars (prior to GS31, 
prior to bud set on the grazing canola, at 10\% flower for the lucerne, and at $20 \mathrm{~cm}$ height for the phalaris/subclover mix). All cereal and grain crops were harvested in late November of each year using a small plot harvester (Kingaroy Engineering Works, Kingaroy, QLD, Australia), with the stubble left undisturbed until planting in the subsequent growing season. The grain yield from each experimental field plot was measured and reported as $\mathrm{T} / \mathrm{h}$.

\subsection{Soil Collection and Weed Seedbank Assessment}

Two shallow soil core samples $(5.5 \mathrm{~cm}$ in diameter, $5 \mathrm{~cm}$ depth) were taken along longitudinal transects within each plot (10 cores per plot) to collect composite soil and weed propagules immediately before planting and immediately after harvest during each growing season (2014-2018). For optimal propagule germination, all samples were stored at $4{ }^{\circ} \mathrm{C}$ until they were eventually spread evenly over the top of a commercial potting mix in shallow seedling flats $(300 \times 350 \times 60 \mathrm{~mm})$ and carefully covered with $1-2 \mathrm{~cm}$ of potting mix [24]. Flats were maintained under glasshouse conditions and watered daily between autumn and early summer, with the emergence of weed seedlings noted at regular bi-monthly intervals. To stimulate germination after each census, the soil in each flat was lightly cultivated by hand. The identification of newly emerged weed seedlings occurred until no further emergence was recorded for three consecutive measurements. The weed seedlings in each tray were counted and the number of seedlings per unit volume was determined and presented as number of plants $/ \mathrm{m}^{3}$ for each sample evaluated. The weed species identified over the 2014-2018 period of screening are presented in Table 2.

Table 2. Common weeds identified in the crop rotational studies in both Wagga Wagga and Condobolin NSW.

\begin{tabular}{|c|c|}
\hline Scientific name & Common name \\
\hline Arctotheca calendula (L.) Levyns & capeweed \\
\hline Atriplex spp. & saltbush \\
\hline Bellis perennis L. & daisy \\
\hline Billardiera fusiformis Labill. & bluebell \\
\hline Bromus diandrus Roth. & brome grass \\
\hline Capsella bursa-pastoris L. & shepherd's purse \\
\hline Cardamine hirsuta L. & bittercress \\
\hline Chenopodium album L. & Lamb's quarters \\
\hline Conyza bonariensis L. & flaxleaf fleabane \\
\hline Crassula sieberiana Domin. & stonecrop \\
\hline Dysphania pumilio (R.Br.) Mosyakin \& Clemants & crumb weed \\
\hline Echium plantagineum L. & Paterson's curse \\
\hline Fumaria officinalis L. & fumitory \\
\hline Gamochaeta calviceps (Fernald) Cabrera & cudweed \\
\hline Hordeum leporinum Link & barley grass \\
\hline Lolium rigidum Gaudin & annual ryegrass \\
\hline Medicago lupulina $\mathrm{L}$. & black medic \\
\hline Panicum spp. & panic grass \\
\hline Papaver rhoeas L. & poppy \\
\hline Polygonum aviculare L. & wireweed \\
\hline Raphanus raphanistrum L. & wild radish \\
\hline Rumex brownii Campd. & rumex \\
\hline Sedum acre L. & stone crop \\
\hline Sisymbrium orientale L. & Indian hedge mustard \\
\hline Sonchus oleraceus L. & sowthistle \\
\hline Stellaria media (L.) Vill. & chickweed \\
\hline Trifolium subterraneum L. & Subterranean clover \\
\hline Vulpia myuros Rchb. & silver grass \\
\hline
\end{tabular}




\subsection{Statistical Analysis}

Trial randomization and design were performed using Agricultural Research Manager Version 9.0 (Gylling Data Management, Inc.) software. The data collected included the total weed seedling number per unit volume of soil samples collected, referred to herein as weed seedling density in each crop rotational treatment field over the entire five-year period, for both locations. Prior to performing ANOVA for randomized the block design experiments with four replications, all data were tested for normality or homogeneity of error (Bartlett's Test). Data were analyzed using $R$ statistical environment software, Version 4.0.3. [28]. To maintain normality, the weed seedling density data required square root transformation. The treatment means were compared using a protected LSD test at $p<0.05$. The weed community structure in each rotational treatment was analyzed using the Shannon diversity index: $\mathrm{H}^{\prime}=-\sum \mathrm{Pi} \ln \mathrm{Pi}$ [29]. The diversity indices between the rotational treatments were compared using ANOVA. Heatmaps were used to compare both the rotational treatments and the year effects on the data from each location, presented separately. In this case, the metadata sets obtained for the total weeds and the individual weed species were generally not homogeneous for variance among rotational treatments, and residuals obtained upon analysis were typically not normally distributed. Therefore, heatmaps were selected as a valid method for visualizing differences among treatments and were constructed using the Heatmap function in R, with the Euclidean distance measure used for hierarchical clustering within the dataset.

\section{Results}

\subsection{Climatic Conditions}

Rainfall received from March to November in 2014, 2017, and 2018 in Wagga Wagga, NSW, was significantly less than the long-term average rainfall of $442 \mathrm{~mm}$ during the winter crop growing season $(389,312$, and $278 \mathrm{~mm}$ respectively), with the region experiencing severe drought conditions (Figure 1). In the 2015 and 2016 growing seasons, rainfall exceeded the long-term average, with 503 and $651 \mathrm{~mm}$ received, respectively, during the growing season. These conditions were conducive to successful winter crop establishment. The average rainfall during the growing season in Condobolin is typically lower than that in Wagga Wagga. The rainfall over 2015-2017 growing seasons exceeded the long-term average for seasonal rainfall of $325 \mathrm{~mm}$ (331, 561, and $395 \mathrm{~mm}$, respectively), while in 2014, precipitation was limited to $289 \mathrm{~mm}$.

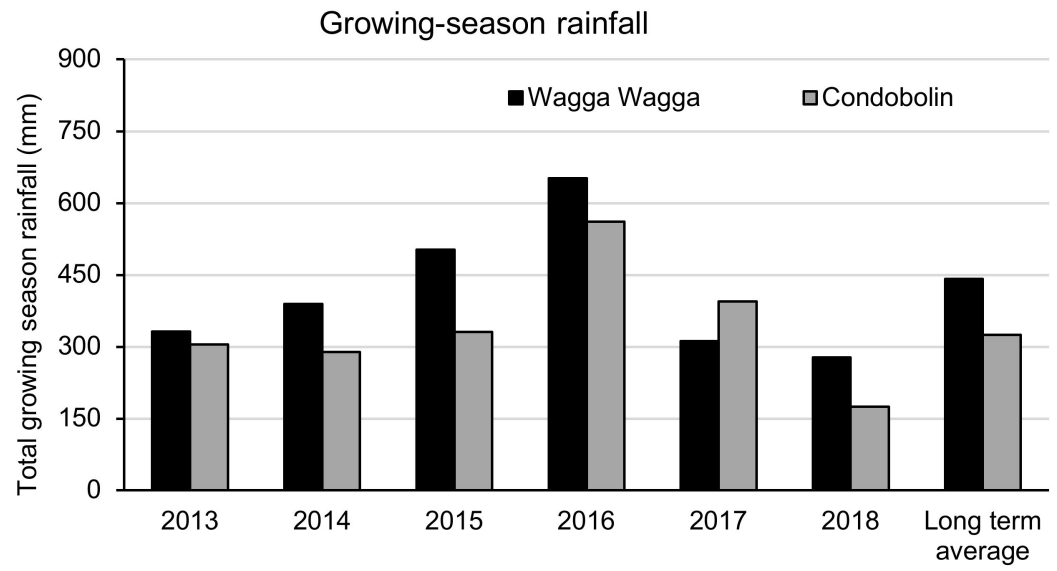

Figure 1. Total precipitation received during the winter growing season (March-November) at the Wagga Wagga and Condobolin study sites from 2013-2018, in contrast to the seventy-year long-term average [30]. 


\subsection{The Impact of Crop Rotational Sequences on the Abundance and Diversity of Key} Annual Weeds

The composition of the weed seedbank revealed the presence of approximately 30 weed species in field soils collected from each rotational crop treatment in Wagga Wagga at experimental initiation, with greater total species diversity noted here than in Condobolin, which harboured approximately 25 weed species. In general, there were fewer weed species noted in the Condobolin rotational plots throughout the course of the study, in contrast to those in Wagga Wagga. The most prevalent weeds in each location included common agronomic weeds associated with broadacre cropping systems, plus several other endemic environmental weeds (Tables S1 and S2). Crassula alata and Sedum spp., while not considered agronomic weeds of significance, were found to dominate the weed seedbank in all rotations in Condobolin, NSW. Of the gramineous weeds, winter-dominant Lolium rigidum and Hordeum glaucum and summer-dominant Panicum spp. were associated with most rotational sequences at both locations (Figure 2.). Polygonum aviculare and Fumaria spp. were observed in most crop rotations and were ranked within the top ten most abundant weed species in Wagga Wagga.

A

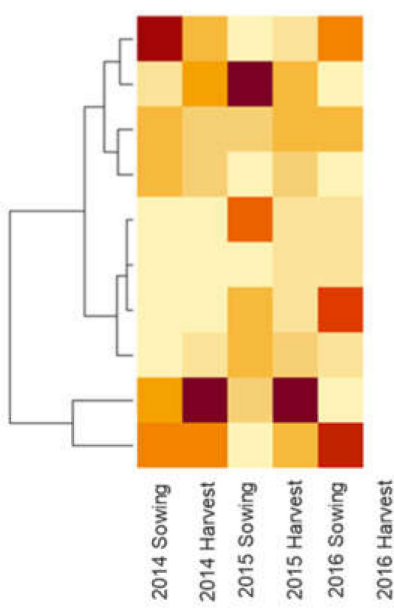

B
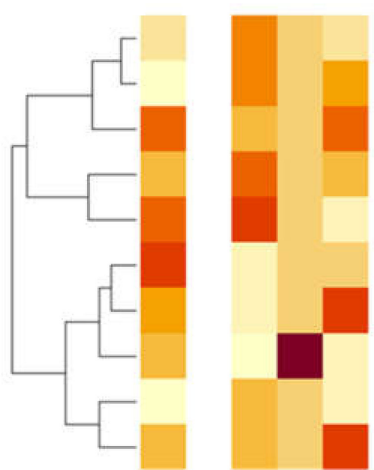
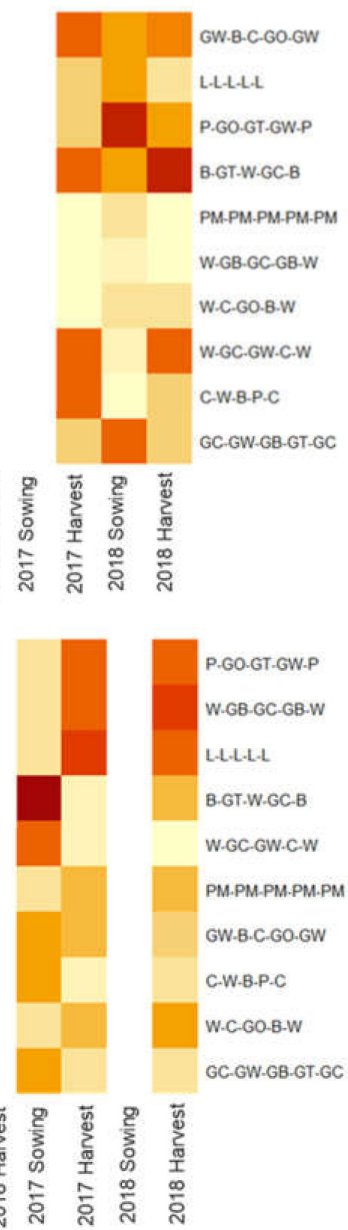

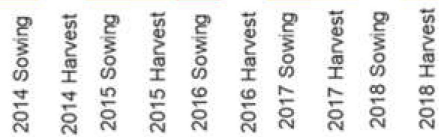

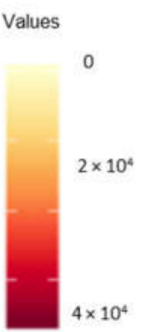

Values

$W C B C C B-W$

W.GB-GC-GB.W

LLLLLLL

B.GT.W.GC.B

W.GC.GW.C.W

PM.PM-PM.PM.PM

GW.B.C.GO.GW

C.W.B.P.C

W.C-GO-B.W

GC.GW.GB.GT.GC

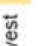

Figure 2. Dendrogram and heat map representing the hierarchical clustering and abundance of the gramineous agronomic weed species (A) Lolium rigidum and (B) Panicum spp. propagules from soil samples collected in rotational treatments established in Wagga Wagga. Samples were collected at both sowing and harvest and are averaged with $n=16$ per treatment. Abbreviations: G, dual-purpose; W, wheat; B, barley; O, oats; C, canola; L, lucerne; P, pulse; T, triticale; PM, Phalaris/subterranean clover. 
After monitoring replicate soil samples collected in year 1, the weed species diversity was uniform across each of the Wagga Wagga and Condobolin experimental sites at initiation, suggesting that the block variation in species was limited, as we attempted to select field sites for uniform weed infestation. The GC-GW-GB-GT-GC rotation contained the most diverse weed species composition when compared to other treatments following five years of annual rotations in Wagga Wagga (Table S3). The exception was the annual pasture mixture treatment, which contained the least weed diversity at experimental completion in 2018. In contrast, in Condobolin, the weed species diversity did not differ between the rotational treatments at experimental termination in 2017. Overall, the weed species diversity was higher in Wagga Wagga in all rotational treatments when compared to Condobolin.

\subsection{The Impact of Selected Crop Rotational Sequences on the Soil Weed Seedbank Density in Wagga Wagga}

The density of weed propagules, including both graminacious and broadleaf species, did not differ between the rotational treatments in 2014, the first year of establishment, suggesting that the weed seedbank was fairly uniform at experimental initiation in Wagga Wagga (Table 3). Grass weed propagule numbers varied over the years $(p<0.0001)$, with the greatest density at experimental initiation in 2014, gradually declining over time, with a reduction in the total soil seedbank of $50 \%$ by $2016(p<0.05)$. However, the weed propagule number increased significantly in 2017 following a period of extended drought. At experimental completion in 2018, grass weed propagules were reduced by $22 \%$ when compared to the numbers present at experimental initiation in 2014. Interestingly, the weed species diversity reflected in soil samples collected from the seedbank in Wagga Wagga did not differ among treatments at experimental initiation in 2014. However, when assessed at the completion of the five year rotational sequence in 2018, the weed species diversity was noteably and significantly different among the rotational treatments (Table S3). In this location, the dual-purpose (grazing) grain crop treatment GC-GW-GB-GT-GC was the most weed-species diverse $(\mathrm{H}=1.397)$ while the annual pasture mixture was the least diverse $(\mathrm{H}=0.674)$.

With respect to total weed propagule numbers, all rotational treatments performed similarly in 2015 and no treatment differences were noted. In 2016, the rotational treatments that included cereal crops influenced weed seedbank numbers. Cereal rotations that included B-GT-W-GC-B, P-GO-GT-GW-P and W-GB-GC-GB-W rotations resulted in weed propagule reductions of $84 \%, 82 \%$, and $94 \%$, respectively, when compared to the leasteffective rotational treatment, a monoculture of lucerne. In 2017, a year impacted by significant drought, reduced weed propagule numbers were also observed in the W-GCGW-C-W sequence followed by C-W-B-P-C, with a reduction of $90 \%$ and $89 \%$, respectively, in comparison to a lucerne monoculture. In the fifth and final year of the experiment (2018), the viable grass propagule numbers as reflected by emerged seedlings were reduced in comparison to the numbers observed at experimental initiation. As in 2017, W-GC-GW-C-W and C-W-B-P-C exhibited reduced numbers of grass propagules in 2018 , with a $64 \%$ and $82 \%$ reduction, respectively, over that observed at experimental initiation $(2014)(p<0.05)$.

Broadleaf weed propagules were generally more numerous than gramineous weed seedlings for all treatments in all years assessed and varied significantly over the fiveyear assessment period $(p<0.05)$, with the highest number recorded in 2018, followed by 2017, and 2014. The lowest numbers were observed in 2017 and 2014. In 2016, the lowest broadleaf weed seed numbers occurred in the W-C-GO-B-W, W-GC-GW-C-W, and GW-B-C-GO-GW treatments, resulting in an $88 \%, 84 \%$ and $81 \%$ reduction, respectively, when compared to the perennial lucerne treatment. In contrast, the weed seed propagules in the lucerne treatment and that of the annual pasture mixture increased by $170 \%$ and $152 \%$, respectively, in 2016 when compared to the numbers at experimental initiation in 2014. In contrast to the seedbank dynamics of the grass weed species, the broadleaf weeds were generally not as successfully suppressed by annual crop rotational sequences. The broadleaf weed seed numbers in the final year of assessment were similar to those at 
experimental initiation, with the exception of the W-GC-GW-C-W rotation, which saw a reduction of $36 \%(p<0.05)$.

Table 3. Weed seed density (propagules $/ \mathrm{m}^{3}$ ) in soils of rotational crop treatments in Wagga Wagga, NSW.

\begin{tabular}{|c|c|c|c|c|c|c|c|c|c|c|}
\hline Rotational crop sequence & 2014 & & 2015 & & 2016 & & 2017 & & 2018 & \\
\hline \multicolumn{11}{|l|}{ Grass weed propagules $/ \mathrm{m}^{3}$} \\
\hline L-L-L-L-L & 25,431 & A & 19,540 & A & 30,460 & A & 57,471 & A & 17,816 & A \\
\hline PM-PM-PM-PM-PM & 14,655 & A & 14,224 & A & 32,759 & $\mathrm{AB}$ & 8908 & $\mathrm{C}$ & 12,787 & $\mathrm{AB}$ \\
\hline GC-GW-GB-GT-GC & 31,322 & $\mathrm{~A}$ & 13,793 & $\mathrm{~A}$ & 10,489 & $\mathrm{ABC}$ & 7328 & $\mathrm{C}$ & 13,506 & $\mathrm{AB}$ \\
\hline GW-B-C-GO-GW & 23,994 & A & 12,213 & A & 6609 & $\mathrm{ABC}$ & 50,719 & $\mathrm{AB}$ & 14,512 & $\mathrm{AB}$ \\
\hline W-C-GO-B-W & - & & 15,948 & A & 8046 & $\mathrm{ABC}$ & 14,224 & $\mathrm{BC}$ & 12,787 & $\mathrm{AB}$ \\
\hline W-GC-GW-C-W & 17,960 & A & 28,879 & A & 4897 & $\mathrm{ABC}$ & 5604 & $\mathrm{C}$ & 6,465 & B \\
\hline C-W-B-P-C & 41,523 & A & 12,213 & A & 18,247 & $\mathrm{ABC}$ & 6753 & $\mathrm{C}$ & 7,471 & B \\
\hline B-GT-W-GC-B & 14,655 & A & 29,742 & A & 4885 & $\mathrm{BC}$ & 26,437 & $\mathrm{ABC}$ & 15,373 & $\mathrm{AB}$ \\
\hline P-GO-GT-GW-P & 14,081 & A & 28,305 & A & 3592 & $\mathrm{C}$ & 11,925 & $\mathrm{BC}$ & 22,126 & A \\
\hline W-GB-GC-GB-W & - & & 17,816 & A & 1868 & $\mathrm{C}$ & 31,322 & $\mathrm{ABC}$ & 15,948 & $\mathrm{AB}$ \\
\hline $\begin{array}{l}\text { LSD }(p=0.05) \text { between rotational treatments } \\
\text { in each year }\end{array}$ & ns & & ns & & 9321 & & 7980 & & 16,662 & \\
\hline \multicolumn{11}{|l|}{ Broadleaf weed propagules $/ \mathrm{m}^{3}$} \\
\hline L-L-L-L-L & 147,270 & A & 181,322 & A & 251,494 & A & 235,201 & A & 193,678 & $\mathrm{~A}$ \\
\hline PM-PM-PM-PM-PM & 105,747 & A & 60,058 & B & 160,632 & $\mathrm{ABC}$ & 60,345 & B & 245,402 & A \\
\hline GC-GW-GB-GT-GC & 64,081 & A & 65,517 & B & 59,310 & $\mathrm{BC}$ & 151,006 & $\mathrm{AB}$ & 98,850 & $\mathrm{AB}$ \\
\hline GW-B-C-GO-GW & 73,276 & A & 67,098 & B & 47,126 & $\mathrm{BC}$ & 78,017 & $\mathrm{AB}$ & 60,632 & $\mathrm{~B}$ \\
\hline P-GO-GT-GW-P & 160,506 & $\mathrm{~A}$ & 237,500 & A & 143,391 & $\mathrm{AB}$ & 126,581 & $\mathrm{AB}$ & 128,736 & $\mathrm{AB}$ \\
\hline W-C-GO-B-W & - & & 110,920 & $\mathrm{AB}$ & 30,172 & $\mathrm{C}$ & 100,719 & $\mathrm{AB}$ & 76,150 & $\mathrm{AB}$ \\
\hline W-GB-GC-GB-W & - & & 88,075 & $A B$ & 51,868 & $\mathrm{C}$ & 135,920 & $\mathrm{AB}$ & 116,810 & $\mathrm{AB}$ \\
\hline B-GT-W-GC-B & 98,563 & $\mathrm{~A}$ & 58,764 & B & 71,034 & $\mathrm{ABC}$ & 100,011 & $\mathrm{AB}$ & 185,776 & $\mathrm{~A}$ \\
\hline W-GC-GW-C-W & 117,385 & A & 87,357 & $\mathrm{AB}$ & 40,086 & $\mathrm{C}$ & 131,466 & $\mathrm{AB}$ & 75,144 & $\mathrm{~B}$ \\
\hline C-W-B-P-C & 62,356 & A & 69,540 & B & 116,092 & $\mathrm{ABC}$ & 129,598 & $\mathrm{AB}$ & 79,310 & B \\
\hline $\begin{array}{l}\text { LSD }(p=0.05) \text { between rotational treatments } \\
\text { in each year }\end{array}$ & ns & & 25,332 & & 26,082 & & 44,944 & & 28,777 & \\
\hline
\end{tabular}

Columns containing the same letters indicate no significant rotational treatment differences $(p<0.05)$. - indicates to rotational crops not sown in 2014. Propagule density consists of combined sowing and harvest time soil samples in each treatment and time point with $n=16$. Data for each year were analyzed separately using ANOVA. ns, not significant.

The most effective rotations in suppressing annual weed propagules in the seedbank over time were those that included diverse cereal crop species and a pulse (C-W-B-P-C) or dual-purpose crop (GC-GW-GB-GT-GC), resulting in reduced propagule numbers $(\sim 50 \%)$ in contrast to the least-competitive perennial lucerne treatment $(p<0.05)$. In comparison, the crop rotations that employed multiple pulse crops and dual-purpose cultivars of cereals, and were also subjected to simulated grazing, (P-GO-GT-GW-P) were much less suppressive and exhibited a similar density of weed seeds to that of the lucerne treatment. The construction of a heat map and the use of hierarchical clustering revealed a clear separation of rotations with respect to overall weed numbers (Figure 3). This particular rotational sequence was clustered with that of the perennial lucerne treatment as the highest in weed number or worst performing, while the sole dual-purpose only sequence, GC-GWGB-GY-GC and C-W-B-P-C, exhibited greater weed species diversity and clustered as the most weed suppressive rotations. 


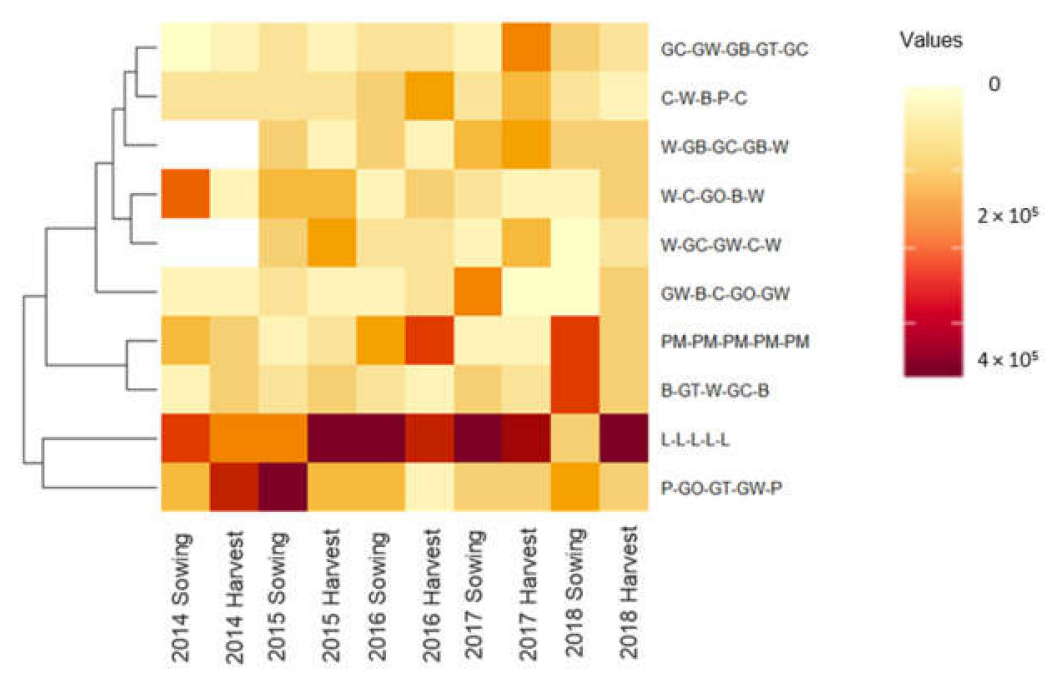

Figure 3. A dendrogram and heat map representing the hierarchical clustering and abundance of total weed propagules from 2014-2018 from composite soil samples collected in the rotational treatments established in Wagga Wagga. Propagule density reflects combined sowing and harvest time soil samples in each treatment and time point with $n=16$. Abbreviations: $\mathrm{G}$, dual-purpose; $\mathrm{W}$, wheat; $\mathrm{B}$, barley; O, oats; C, canola; L, lucerne; P, pulse; T, triticale; PM, Phalaris/subterranean clover.

\subsection{The Impact of Selected Crop Rotational Sequences on the Soil Weed Seedbank Density in Condobolin}

Similar to the weed seedbank dynamics observed in Wagga Wagga, broadleaf weed propagules accounted for the majority of weed seedlings observed at Condobolin over the three-year assessment period (Table 4 ). The total graminaceous weed seed propagules over the three year period differed significantly over the years $(p<0.05)$ with the greatest density observed at experimental initiation in 2015. The weed seedbank in the following year was impacted by the crop rotational treatment, with the B-C-GO exhibiting the highest grass weed seed density and the perennial lucerne treatment the lowest. This was in direct contrast to the observations at Wagga Wagga, where the crop rotations predominantly containing cereals showed a reduction in the propagule numbers and in the resulting weed seedlings. Propagule numbers in 2016 were significantly reduced in all rotational treatments, with the GB-GC-GB and GC-GW-C treatments exhibiting no grass weed infestation in the soil samples collected. However, grass weed propagule numbers rebounded significantly $(p<0.05)$ in all treatments in 2017, a season with reduced crop growth and yields due to extreme drought. The weed species diversity reflected in the soil samples collected from the rotational treatments in Condobolin was not significantly different at either experimental initiation or termination (Table S3).

The broadleaf weed propagule numbers declined over time in all rotational treatments, except for lucerne $(p<0.05)$. In this case, the broadleaf propagule numbers doubled in 2016 and 2017 in the lucerne soil samples when compared to those collected at experimental initiation in 2015. The crop rotational sequences GT-W-GC, GB-GC-GB and GO-GT-GW, all containing a majority of dual-purpose or grazing cereal crops, also showed reduced broadleaf weed propagule numbers in contrast to those at experimental initiation in 2014, generating $80 \%, 75 \%$, and $66 \%$ reductions, respectively. The rotational treatments in Wagga Wagga containing wheat, canola plus grazing wheat, or canola also suppressed the broadleaf weed numbers most successfully. 
Table 4. Weed seed density (propagules $/ \mathrm{m}^{3}$ ) in soil samples collected from 2015-2017 rotational crop treatments in Condobolin, NSW.

\begin{tabular}{|c|c|c|c|c|c|c|}
\hline Rotational crop sequence & \multicolumn{2}{|l|}{2015} & \multicolumn{2}{|l|}{2016} & \multicolumn{2}{|l|}{2017} \\
\hline \multicolumn{7}{|l|}{ Grass weed propagules $/ \mathrm{m}^{3}$} \\
\hline B-C-GO & 8621 & A & 144 & A & 4023 & A \\
\hline C-GO-B & 8046 & $\mathrm{AB}$ & 1149 & $\mathrm{~A}$ & 3448 & $\mathrm{~A}$ \\
\hline GB-GC-GB & 5747 & $\mathrm{AB}$ & 0 & $\mathrm{~A}$ & 2730 & A \\
\hline GC-GW-C & 5316 & $\mathrm{AB}$ & 0 & A & 9626 & A \\
\hline GO-GT-GW & 6035 & $\mathrm{AB}$ & 287 & A & 3305 & A \\
\hline GT-W-GC & 7471 & $\mathrm{AB}$ & 1437 & $\mathrm{~A}$ & 3592 & A \\
\hline GW-GB-GT & 6609 & $\mathrm{AB}$ & 287 & A & 5029 & A \\
\hline L-L-L & 3305 & B & 287 & $\mathrm{~A}$ & 7471 & A \\
\hline W-B-W & 5460 & $\mathrm{AB}$ & 144 & $\mathrm{~A}$ & 5188 & $\mathrm{~A}$ \\
\hline $\begin{array}{l}\mathrm{LSD}(p=0.05) \text { between rotational } \\
\text { treatments in each year }\end{array}$ & 1354 & & ns & & ns & \\
\hline \multicolumn{7}{|l|}{ Broadleaf weed propagules $/ \mathrm{m}^{3}$} \\
\hline L-L-L & 191,092 & $\mathrm{~A}$ & 413,362 & $\mathrm{~A}$ & 96,552 & $\mathrm{~A}$ \\
\hline B-C-GO & 181,178 & $\mathrm{~A}$ & 92,098 & $\mathrm{~B}$ & 65,517 & $\mathrm{AB}$ \\
\hline C-GO-B & 161,063 & $\mathrm{~A}$ & 117,529 & B & 52,586 & $\mathrm{AB}$ \\
\hline GB-GC-GB & 164,224 & $\mathrm{~A}$ & 83,908 & B & 41,810 & $\mathrm{~B}$ \\
\hline GC-GW-C & 151,437 & A & 104,023 & B & 46,839 & $\mathrm{~B}$ \\
\hline GO-GT-GW & 106,465 & A & 126,868 & $\mathrm{~B}$ & 36,207 & $\mathrm{~B}$ \\
\hline GT-W-GC & 167,960 & $\mathrm{~A}$ & 124,466 & $\mathrm{~B}$ & 33,477 & $\mathrm{~B}$ \\
\hline GW-GB-GT & 205,891 & $\mathrm{~A}$ & 118,678 & B & 43,678 & B \\
\hline W-B-W & 113,219 & A & 110,345 & $\mathrm{~B}$ & - & \\
\hline $\begin{array}{l}\mathrm{LSD}(p=0.05) \text { between rotational } \\
\text { treatments in each year }\end{array}$ & ns & & 29,104 & & 55,864 & \\
\hline
\end{tabular}

Columns containing the same letters indicate no significant rotational treatment differences $(p<0.05)$. - indicates to rotational crops not sown in 2014. Propagule density consists of combined sowing and harvest time soil samples in each treatment and time point with $n=16$. Data for each year were analyzed separately using ANOVA. ns, not significant.

At the Condobolin site, all annual crop rotations contributed to a reduction in the weed seed propagules $(p<0.05)$ over the three-year assessment period in contrast to the lucerne treatment (Figure S1). Hierarchical clustering supported this observation (Figure 4). The GO-GT-GW rotation and the W-B-W rotation clustered together, amounting to the lowest density of weed propagules. All other annual rotations clustered together, indicating similar densities of weeds over the duration of the experiment.

\subsection{Crop Yield}

Crop yields were evaluated for each treatment within the 2015-2018 field assessment years (Table 5), with grain yields comparable to those typical for each region in years with adequate rainfall. For example, in the year 2016, wheat and barley harvests (grain-only or dual-purpose) ranged between 4.6-5.2 $\mathrm{T} /$ ha in Wagga Wagga. In the same period in Condobolin, under conditions with lower-than-average rainfall, cereal grain yields ranged from 1.4-3.7 T/ha. The grain yields under optimal growth conditions in 2016 were greater than the annual average in both locations. In 2017 and 2018, the grain yields were significantly reduced in both quality and quantity. Warm and dry conditions adversely impacted the canola yields, with plants undergoing senescence as drought conditions intensified, resulting in no harvestable yield. Wheat, barley, and oat were similarly impacted, with up to a $90 \%$ reduction in grain yield. 


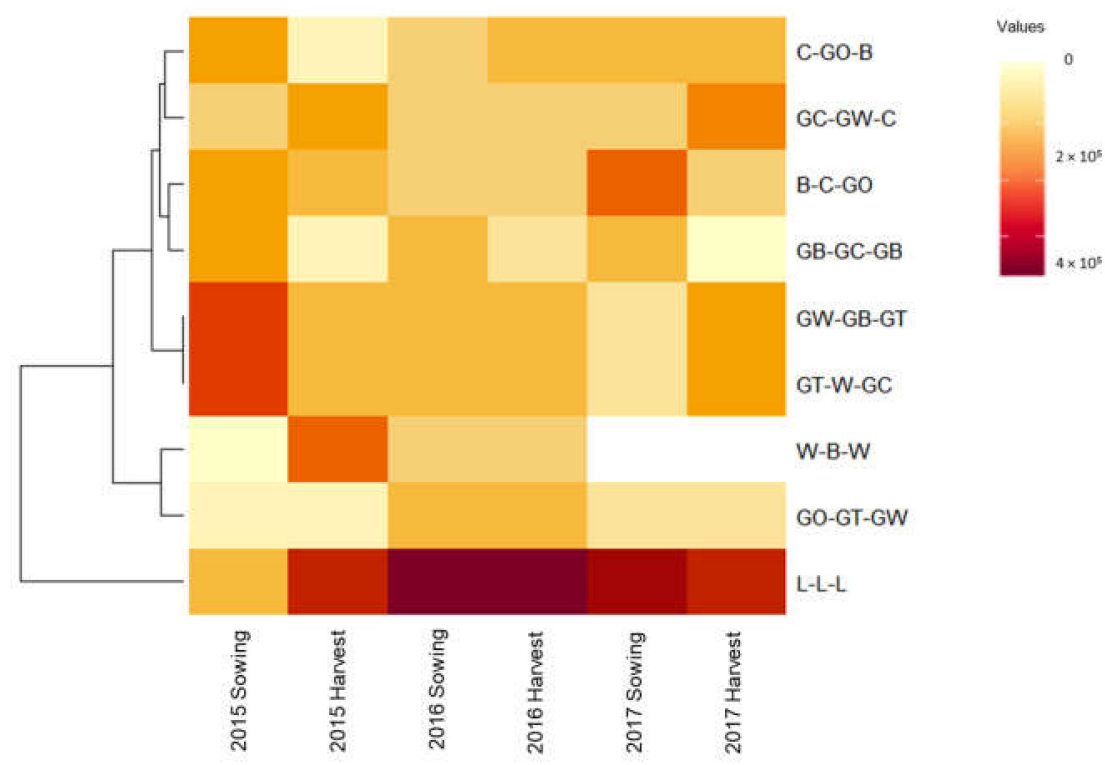

Figure 4. Dendrogram and heat map representing the hierarchical clustering and abundance of total weed propagules from composite soil samples collected from 2015-2017 in rotational treatments established in Condobolin. Propagule density reflects combined sowing and harvest time soil samples in each treatment and time point with $n=16$. Abbreviations: $\mathrm{G}$, dual-purpose; $\mathrm{W}$, wheat; $\mathrm{B}$, barley; $\mathrm{O}$, oats; C, canola; L, lucerne; P, pulse; T, triticale; PM, Phalaris/subterranean clover.

Table 5. Average grain yield (t/ha) for cereal, dual-purpose and pulse rotational crops established in Wagga Wagga and Condobolin, NSW.

\begin{tabular}{|c|c|c|c|c|c|c|}
\hline Location & Crop rotational sequence & 2014 & 2015 & 2016 & 2017 & 2018 \\
\hline \multirow{10}{*}{$\begin{array}{l}\text { Wagga } \\
\text { Wagga }\end{array}$} & B-GT-W-GC-B & - & 2.5 & 4.6 & 0.0 & 1.1 \\
\hline & C-W-B-P-C & - & 1.1 & 5.1 & 0.4 & 1.6 \\
\hline & GC-GW-GB-GT-GC & - & 0.9 & 5.0 & 1.3 & 0.8 \\
\hline & GW-B-C-GO-GW & - & 1.7 & 1.3 & 0.6 & 0.1 \\
\hline & L-L-L-L-L & NA & NA & NA & NA & NA \\
\hline & P-GO-GT-GW-P & - & 3.4 & 1.6 & 0.9 & 1.5 \\
\hline & PM-PM-PM-PM-PM & NA & NA & NA & NA & NA \\
\hline & W-C-GO-B-W & - & 2.1 & 2.8 & 1.8 & 0.7 \\
\hline & W-GB-GC-GB-W & - & 2.6 & 1.3 & 1.1 & 0.1 \\
\hline & W-GC-GW-C-W & - & 2.0 & 4.6 & 0.0 & 0.7 \\
\hline \multirow[t]{9}{*}{ Condobolin } & B-C-GO & & 1.8 & 1.6 & 0.1 & \\
\hline & C-GO-B & & - & 3.4 & 0.3 & \\
\hline & GB-GC-GB & & 1.7 & 0.1 & - & \\
\hline & GC-GW-C & & 0.0 & 3.5 & 0.1 & \\
\hline & GO-GT-GW & & 0.0 & 1.4 & 0.4 & \\
\hline & GT-W-GC & & 0.1 & 3.5 & - & \\
\hline & GW-GB-GT & & 0.3 & 3.4 & 0.2 & \\
\hline & L-L-L & & NA & NA & NA & \\
\hline & W-B-W & & 1.2 & 3.7 & - & \\
\hline
\end{tabular}

- means not harvested; NA means not applicable.

\section{Discussion}

A diverse spectrum of regionally common winter and summer annual weed species was noted at both experimental research sites in southern NSW when above-ground ratings of weed assessment were performed. Greater weed diversity was noted at the Wagga Wagga site in contrast to the Condobolin site, which received less total annual precipitation. The soil sampling of the weed seedbank resulting from rotational treatments was performed twice yearly and reflected a similar weed spectrum to that noted in the 
above-ground ratings (Table 2) [31], suggesting that the assessment of the weed seedbank by the germination of soil samples over an 18-month period for each sample provided a comparable evaluation of the actual weed spectrum present at the site. However, in contrast to the aboveground weed assessment, the trends in weed abundance noted in the assessed soil seedbank provided valuable insights into the legacy effects of the previous crop in a selected rotational sequence [27]. In both study sites, we observed that the location and corresponding seasonal conditions, the choice of a rotational crop, and the sequence clearly impacted the propagule density and composition of the soil seedbank over time.

The selection of experimental sites for this study took into consideration the impact of location, soil type, and associated climatic conditions encountered, and the sites impacted the performance of the rotational crop sequences investigated. Condobolin typically experiences a dry cropping season with a uniform monthly distribution of rainfall, but approximately 25-30\% less yearly rainfall $(325 \mathrm{~mm}$ ) than Wagga Wagga, which receives moderate rainfall $(440 \mathrm{~mm})$ with higher precipitation in the winter months. Cereal and pasture crop yields in Condobolin are typically 50\% of those found in Wagga Wagga, generally due to moisture limitations on crop yield and severe climatic extremes, including frost events and excessive heat that limit grain production [30]. Weed seedbank numbers varied by over three-fold between the two experimental locations at experiment initiation for broadleaf weed species, with Condobolin soils containing the most viable weed seeds as assessed by the glasshouse weed seedling emergence experiments.

Previous studies comparing rotational crop diversity have shown that monocultures and less diverse crop rotations tend to reduce the inherent species diversity of the weed seedbank over time, as reflected in weed seedling emergence [32]. Reduced weed species diversity may result from the selection of those weed species suitably adapted for competition in cereal-dominated or other monocultures. In this study, weed seedbank dynamics were estimated by the evaluation of weed seedling emergence over an 18-month window following soil sampling for weed propagules. Weed seedbank thresholds were also estimated twice per year in each rotational treatment in this study, both at the time of sowing in winter and crop harvesting in late spring to summer. By collecting soil samples yearly at the time of crop harvest, we obtained a more accurate estimate of the viable weed seed density encountered in-crop each year, whereas the collection at sowing reflected the impact of crop residues and fallow upon the total seedbank.

Following the five-year rotational sequence in Wagga Wagga, treatments containing competitive cereal crops (wheat, barley, oats, and triticale) significantly reduced the weed seedbank, likely due to the optimal crop growth and development, providing considerable competition for weed establishment. Similar findings were reported in experiments evaluating the performance of competitive canola cultivars and wheat genotypes at this location $[13,21]$. The low average rainfall at Condobolin, along with the reduced seeding density in the crops in this region, also consistently impacted the early crop vigour observed from 2015-2017. During years of prolonged drought, it was not unusual to produce less than $1 \mathrm{~T}$ /ha yields from various grain and cereal crops in Condobolin.

In Wagga Wagga, the most effective rotations for the reduction of the total propagule numbers in the weed seedbank were the cereal only rotations, which performed consistently better than those of perennial lucerne or mixed pasture with respect to propagule density in the seedbank, as estimated by soil sampling over time. At Wagga Wagga, the crop rotational sequence C-W-B-P-C and the dual-purpose crop rotation GC-GW-GB-GT-GC were found to be the best performers with respect to the reduction of the weed seedbank while also maintaining enhanced diversity of the weed species in the seedbank. The C-W-B-P-C rotational sequence also provided distinct advantages with respect to the management of common annual weeds in dryland rotations. For example, planting canola in year 1 of a rotation would enable the targeted control of gramineous weeds, including herbicide-resistant annual ryegrass, using multiple selective pre-emergent herbicides [33]. In low input, no tillage, or conservation tillage systems, a subsequent competitive wheat or barley crop following canola can typically provide fierce weed competition due to early vigour traits expressed by 
these cereals [33]. Pulse and other legumes that follow cereal crops benefit from a depleted weed seedbank and can generally fix substantial atmospheric nitrogen, further benefiting the subsequent canola crop and its related yields [34]. Thus, agronomically, the C-W-B-P-C rotational crop sequence provides Australian grain growers an opportunity for optimising total yields while potentially reducing the input costs associated with weed management and enhanced fertility.

The trends in weed seedbank dynamics observed among both locations from 2014-2017 were similar in that the weed seedbank densities generally declined over time in both Wagga Wagga and Condobolin. The selection of cultivars with the ability to compete successfully with weeds in-crop was clearly associated with subsequent annual reductions in weed seedbank density. In this case, the establishment of cereal cultivars with closed canopies resulted in successful competition with weeds for resources, including photosynthetically active radiation and moisture. Consequently, these competitive traits were potentially important in the suppression of weeds in both canola, wheat, and other cereals, leading to a reduced weed fecundity [13].

The optimal performance of rotational crops may also result in an improved yield, resulting in additional profits for producers and the potentially reduced frequency of the application of post-emergence herbicides. In contrast to more competitive cereal cultivars, the establishment of perennial lucerne resulted in a dramatic increases in viable weed seeds and subsequent seedlings but a less-diverse cohort of weeds than those observed in the grain crop dominated rotations. This was particularly evident in the years experiencing drought, where fewer weeds were observed initially, but seedbank numbers increased due to a less competitive lucerne crop (i.e., 2017 and 2018). Following a three-year decline in seedbank numbers in nearly all rotations, some weeds experienced a significant rebound in propagule numbers in 2017 at harvest and in 2018 at sowing, as evidenced by subsequent weed establishment. This was not unexpected due to the sub-optimal crop growth due to extended drought. However, in Wagga Wagga, by the 2018 harvest, weed seed numbers again declined over levels observed at experimental initiation, with the exception of the lucerne treatment. It should be noted that in contrast to the broadacre crops, while the lucerne establishment was successful, a dense canopy was not achieved, allowing significant light and space for weed establishment.

Interestingly, the number and diversity of the broadleaf weeds was greater than the monocotyledonous weeds at both locations. Previous studies have shown that in general, grass weed species in Australia require between 12-18 months for complete depletion from the soil seed bank, in contrast to broadleaf weeds, which can require many years for complete depletion, owing to seed coat persistence, seed dormancy, and other factors including microbial activity in the soil $[35,36]$. The combination of high rates of seed production and persistence in the seed bank often accounts for the persistence of broadleaf weeds over time, highlighting the importance of combining chemical control along with cultural practices including the use of competitive crop varieties or cultivars for the control of such weeds in broadacre crops. In our studies, the dramatic impact of the weed seedbank persistence was evidenced by flushes of broadleaf weed emergence under favourable soil moisture and environmental conditions at both sites following 18 months of prolonged drought.

Certain species of weeds responded differentially to rotational treatments over time. For example, annual ryegrass was prevalent across both sites, but its response to rotational selection was location-dependant, possibly due to differential rainfall patterns. This was evident in the timing of weed germination, with numerous flushes occurring at both the Condobolin and Wagga Wagga sites in 2016. The variability of the presence of viable annual ryegrass seed in the soil sampling over successive years suggested that ryegrass weed seeds typically did not persist more than one year in the soil seedbank. Viable ryegrass seeds may also have been subject to predation, or microbial degradation, as previously described by Chee-Sanford et al. [36].

Fumaria species in the Riverina region of NSW also pose a continual challenge for control, particularly in the broadacre crops, due to limitations in selective herbicide op- 
tions [37]. Fumaria is known to persist in the seedbank for up to 20 years, rendering control difficult, if not impossible [38]. Given the inherent dormancy associated with Fumaria, it is not surprising that the seedbank density observed was highly variable over the five-year assessment period. In Wagga Wagga, the seedbank generally declined over five years from the time of sowing, suggesting that under typical conditions, viability declined rapidly in most rotational treatments. However, seed numbers were the highest in the perennial lucerne pasture rotation, particularly in 2017 during less-favourable cropping conditions. Fumaria spp. was less common in Condobolin, most likely due to its preference for soils with a higher moisture retention and high rainfall, where it flourishes under optimal growing conditions.

The seed density of the summer annual weed Panicum spp. was highest in the years that experienced optimal rainfall (such as 2015), benefiting from the higher soil moisture throughout the growing season, with variable seedbank dynamics following a similar trend to that of fumitory over the course of the study. It is evident that the weed seed density at the time of harvest in the higher rainfall years was low, potentially due to in-crop suppression of this weed and the germination of most of the weed seeds before harvest. A comprehensive study of the biology of Panicum spp. has not yet been performed in southern Australia; therefore, it is difficult to draw conclusions about seed dynamics, including the development of dormancy resulting in enhanced persistence. However, Panicum spp. is considered to be tolerant to drought and to remain competitive during low soil moisture conditions. Recent surveys revealed that the majority of Panicum spp. identified in Wagga Wagga and Condobolin were Panicum hillmanii [39].

Regardless of the weed species, the significant depletion of the total weed seedbank through the selective establishment of more competitive wheat, oat, barley, and canola cultivars is clearly an important finding resulting from this and other studies performed in the Riverina region of NSW [13]. Furthermore, the impact of crop residues on the depletion of the weed seed bank density has been pointed out in studies performed by Mwendwa et al. [12] and others [40-42]. In this case, our findings indicate that the cultivar or rotational crop selection can result in a 35\% to $70 \%$ difference in residual seedbank numbers over time. The establishment of successful crop or pasture rotations may reduce propagule numbers but may also generate greater selective pressure for the establishment of key weed species in such rotations over time (i.e., cereal/pulse or pasture legume mixture). Interestingly, the inclusion of the crop rotational sequence containing only the dual-purpose cereals of canola, wheat, barley, triticale, and canola resulted in the greatest weed species diversity in the seedbank. The prostrated early growth habits of these crops and the presence of multiple crop residues on the soil surface over time may have contributed to a low overall weed abundance and resulted in a more diverse weed species seedbank [43]. A concurrent study conducted in Wagga Wagga evaluating the weed-suppressive potential of dualpurpose cereal crops showed that appropriately timed grazing reduced the emergence of annual ryegrass in the subsequent cereal crop [44]. The removal of weed seed heads through mowing, which simulated traditional grazing activity, may also have significantly impacted the fecundity of selected weed species. Additional studies with dual-purpose crops may show promise for seedbank reduction and should potentially be attempted across multiple locations.

In conclusion, the soil seedbank of gramineous and broadleaf weeds was generally reduced by the inclusion of weed-competitive cereal, annual pasture, and pulse crops in annual rotations under conditions conducive to rapid crop establishment and growth, resulting in canopy closure and reduced competition by weeds for radiation, water, and nutrients. The development of drought-tolerant cereal crops including triticale, barley, and oats may support more continuous crop competition for resources in years when soil moisture is limited, and crops are typically less competitive with certain drought tolerant weeds. In Australia, drought conditions could be experienced in five out of ten years, depending on local weather patterns. Additional studies based on crop selection, weeds present, climate, and available soil moisture to further evaluate the community 
dynamics of selected annual weed species over time would be useful to develop predictive models for producers using these rotations. In addition, the integration of various weed control strategies including chemical control, grazing, harvest weed seed destruction, chafflining, and targeted tillage may also be considered when developing rotational strategies to effectively reduce propagule numbers in the soil seedbank.

Supplementary Materials: The following supporting information can be downloaded at: https: / / www.mdpi.com/article/10.3390/agronomy12020375/s1. Supplementary Material: Figure S1: Weed propagule numbers obtained in rotational cropping treatments from 2014-2018 in Wagga Wagga and 2015-2017 in Condobolin, NSW; Table S1: Weed species most prevalent in crop rotational sequences evaluated in Wagga Wagga; Table S2: Weed species most prevalent in crop rotational sequences evaluated in Condobolin; Table S3: Weed species diversity (Shannon-Weiner diversity index) in soil samples collected from cereal and pasture rotations established in Wagga Wagga and Condobolin at experimental initiation and completion of the rotational sequence.

Author Contributions: Conceptualization, W.B.B. and L.A.W.; methodology and investigation, W.B.B., K.M.S.H., S.G. and L.A.W.; data curation, K.M.S.H.; data analysis S.G., K.M.S.H. and P.A.W.; manuscript draft preparation, S.G., K.M.S.H. and L.A.W.; writing, reading and editing; S.G., K.M.S.H. and L.A.W. All authors have read and agreed to the published version of the manuscript.

Funding: This research was funded by the Australian Grains Research Development Corporation, grant number: UCS00020.

Data Availability Statement: Data generated from this work is available with the corresponding author for a period of five years from publication as per funding guidelines.

Acknowledgments: The authors further acknowledge the assistance from Pieter-Willem Hendriks to produce graphical outputs in R. Authors acknowledge technical assistance provided by Graeme Heath and the Plant Interactions Research Team.

Conflicts of Interest: The authors declare no conflict of interest.

\section{References}

1. Robertson, M.J.; Holland, J.F.; Bambach, R. Response of canola and Indian mustard to sowing date in the grain belt of north-eastern Australia. Aust. J. Exp. Agric. 2004, 44, 43-52. [CrossRef]

2. Value of Agricultural Commodities Produced, Australia, 2019-2020 Financial Year I Australian Bureau of Statistics. Available online: https:/ / www.abs.gov.au/statistics/industry/agriculture/value-agricultural-commodities-produced-australia/latestrelease (accessed on 22 November 2021).

3. Peters, R.; Sturz, A.; Carter, M.; Sanderson, J. Developing disease-suppressive soils through crop rotation and tillage management practices. Soil Tillage Res. 2003, 72, 181-192. [CrossRef]

4. Mitran, T.; Meena, R.S.; Lal, R.; Layek, J.; Kumar, S.; Datta, R. Role of Soil Phosphorus on Legume Production. In Legumes for Soil Health and Sustainable Management; Springer Science and Business Media LLC: Berlin/Heidelberg, Germany, 2018 ; pp. 487-510.

5. Hufnagel, J.; Reckling, M.; Ewert, F. Diverse approaches to crop diversification in agricultural research. A review. Agron. Sustain. Dev. 2020, 40, 14. [CrossRef]

6. Bell, M.; Seymour, N.; Stirling, G.R.; Stirling, A.M.; Van Zwieten, L.; Vancov, T.; Sutton, G.; Moody, P. Impacts of management on soil biota in Vertosols supporting the broadacre grains industry in northern Australia. Soil Res. 2006, 44, 433-451. [CrossRef]

7. Seymour, M.; Kirkegaard, J.; Peoples, M.B.; White, P.F.; French, R.J. Break-crop benefits to wheat in Western Australia-Insights from over three decades of research. Crop Pasture Sci. 2012, 63, 1-16. [CrossRef]

8. Peterson, M.A.; Collavo, A.; Ovejero, R.; Shivrain, V.; Walsh, M.J. The challenge of herbicide resistance around the world: A current summary. Pest Manag. Sci. 2018, 74, 2246-2259. [CrossRef] [PubMed]

9. Broster, J.C.; Pratley, J.E.; Ip, R.H.L.; Ang, L.-M.; Seng, K.P. A quarter of a century of monitoring herbicide resistance in Lolium rigidum in Australia. Crop Pasture Sci. 2019, 70, 283-293. [CrossRef]

10. Owen, M.J.; Walsh, M.J.; Llewellyn, R.S.; Powles, S.B. Widespread occurrence of multiple herbicide resistance in Western Australian annual ryegrass (Lolium rigidum) populations. Aust. J. Agric. Res. 2007, 58, 711-718. [CrossRef]

11. Bajwa, A.; Latif, S.; Borger, C.; Iqbal, N.; Asaduzzaman, M.; Wu, H.; Walsh, M. The Remarkable Journey of a Weed: Biology and Management of Annual Ryegrass (Lolium rigidum) in Conservation Cropping Systems of Australia. Plants 2021, $10,1505$. [CrossRef] [PubMed]

12. Mwendwa, J.M.; Jeffrey, D.W.; Weston, L.A. The use of allelopathy and competitive crop cultivars for weed suppression in cereal crops. In Integrated Weed Management for Sustainable Agriculture; Burleigh Dodds Science Publishing: Cambridge, UK, 2018; pp. $361-388$. 
13. Mwendwa, J.; Brown, W.B.; Wu, H.; Weston, P.A.; Weidenhamer, J.D.; Quinn, J.; Weston, L. The weed suppressive ability of selected Australian grain crops; case studies from the Riverina region in New South Wales. Crop. Prot. 2018, 103, 9-19. [CrossRef]

14. Schuster, M.Z.; Harrison, S.K.; de Moraes, A.; Sulc, R.M.; Carvalho, P.C.F.; Lang, C.R.; Anghinoni, I.; Lustosa, S.B.C.; Gastal, F. Effects of crop rotation and sheep grazing management on the seedbank and emerged weed flora under a no-tillage integrated crop-livestock system. J. Agric. Sci. 2018, 156, 810-820. [CrossRef]

15. Broster, J.; Rayner, A.; Ruttledge, A.; Walsh, M.J. Impact of stripper fronts and chaff lining on harvest weed seed control. In Proceedings of the GRDC Grains Research Update, West Wyalong, Australia, 25 July 2018; pp. 55-61.

16. Walsh, M.J.; Harrington, R.B.; Powles, S.B. Harrington Seed Destructor: A New Nonchemical Weed Control Tool for Global Grain Crops. Crop Sci. 2012, 52, 1343-1347. [CrossRef]

17. Chauhan, B.; Singh, R.G.; Mahajan, G. Ecology and management of weeds under conservation agriculture: A review. Crop Prot. 2012, 38, 57-65. [CrossRef]

18. Bertin, C.; Yang, X.; Weston, L.A. The role of root exudates and allelochemicals in the rhizosphere. Plant Soil 2003, $256,67-83$. [CrossRef]

19. Jabran, K.; Mahajan, G.; Sardana, V.; Chauhan, B.S. Allelopathy for weed control in agricultural systems. Crop. Prot. 2015, 72, 57-65. [CrossRef]

20. Van der Meulen, A.; Chauhan, B. A review of weed management in wheat using crop competition. Crop. Prot. 2017, 95, 38-44. [CrossRef]

21. Mwendwa, J.M.; Brown, W.B.; Weston, P.A.; Haque, K.M.S.; Preston, C.; Weston, L.A. Evaluation of selected commercial oilseed rape cultivars for early vigour, weed suppression and yield in southern New South Wales. Weed Res. 2020, 60, 450-463. [CrossRef]

22. Weisberger, D.; Nichols, V.; Liebman, M. Does diversifying crop rotations suppress weeds? A meta-analysis. PLoS ONE 2019, 14, e0219847. [CrossRef]

23. Latif, S.; Gurusinghe, S.; Weston, P.A.; Brown, W.B.; Quinn, J.C.; Piltz, J.W.; Weston, L.A. Performance and weed-suppressive potential of selected pasture legumes against annual weeds in south-eastern Australia. Crop Pasture Sci. 2019, 70, 147-158. [CrossRef]

24. Kleemann, S.G.L.; Preston, C.; Gill, G.S. Influence of Management on Long-Term Seedbank Dynamics of Rigid Ryegrass (Lolium rigidum) in Cropping Systems of Southern Australia. Weed Sci. 2016, 64, 303-311. [CrossRef]

25. Butkevičienè, L.; Skinulienė, L.; Auželienė, I.; Bogužas, V.; Pupalienė, R.; Steponavičienè, V. The Influence of Long-Term Different Crop Rotations and Monoculture on Weed Prevalence and Weed Seed Content in the Soil. Agronomy 2021, 11, 1367. [CrossRef]

26. Adeux, G.; Munier-Jolain, N.; Meunier, D.; Farcy, P.; Carlesi, S.; Barberi, P.; Cordeau, S. Diversified grain-based cropping systems provide long-term weed control while limiting herbicide use and yield losses. Agron. Sustain. Dev. 2019, 39, 42. [CrossRef]

27. Cordeau, S.; Baudron, A.; Farcy, P.; Vieren, E.; Smith, R.; Munier-Jolain, N.; Adeux, G. Legacy effects of contrasting long-term integrated weed management systems. Front. Agron. 2021, 3, 111. [CrossRef]

28. R Core Team. R: A Language and Environment for Statistical Computing. R Foundation for Statistical Computing: Vienna, Austria, 2018; Available online: https:/ / www.R-project.org/ (accessed on 13 December 2021).

29. Konopiński, M.K. Supplemental Information 7: R code. Peer] 2020, 8, e9391. [CrossRef] [PubMed]

30. Australian Government Bureau of Meteorology. Available online: http://www.bom.gov.au/climate/data/index.shtml? bookmark=136\&zoom=3\&lat=-32.5355\&lon=147.74\&layers=B00000TFFFFFFFTFFFFFFFFFFFFFFFFFFFFTTT\&dp=IDC10002-d (accessed on 13 December 2021).

31. Mwendwa, J.M.; Brown, W.B.; Weidenhamer, J.D.; Weston, P.A.; Quinn, J.C.; Wu, H.; Weston, L.A. Evaluation of Commercial Wheat Cultivars for Canopy Architecture, Early Vigour, Weed Suppression, and Yield. Agronomy 2020, 10, 983. [CrossRef]

32. Murphy, S.D.; Clements, D.; Belaoussoff, S.; Kevan, P.G.; Swanton, C.J. Promotion of weed species diversity and reduction of weed seedbanks with conservation tillage and crop rotation. Weed Sci. 2006, 54, 69-77. [CrossRef]

33. Shah, K.K.; Modi, B.; Pandey, H.P.; Subedi, A.; Aryal, G.; Pandey, M.; Shrestha, J. Diversified Crop Rotation: An Approach for Sustainable Agriculture Production. Adv. Agric. 2021, 2021, 8924087. [CrossRef]

34. Angus, J.F.; Kirkegaard, J.; Hunt, J.R.; Ryan, M.; Ohlander, L.; Peoples, M.B. Break crops and rotations for wheat. Crop. Pasture Sci. 2015, 66, 523-552. [CrossRef]

35. Mahajan, G.; Walsh, M.; Chauhan, B.S. Junglerice (Echinochloa colona) and feather fingergrass (Chloris virgata) seed production and retention at sorghum maturity. Weed Technol. 2020, 34, 272-276. [CrossRef]

36. Chee-Sanford, J.C.; Williams, M.M.; Davis, A.S.; Sims, G.K. Do microorganisms influence seed-bank dynamics? Weed Sci. 2006, 54, 575-587. [CrossRef]

37. Jourdan, M.; Vitou, J.; Thomann, T.; Maxwell, A.; Scott, J.K. Potential biological control agents for fumitory (Fumaria spp.) in Australia. In Proceedings of the XII International Symposium on Biological Control of Weeds, La Grande Motte, France, 22-27 April 2007; CABI: Wallingford, UK, 2008; pp. 160-164.

38. Norton, G.M. Understanding the Success of Fumitory as a Weed in Australia. Charles Sturt University: Wagga Wagga, Australia, 2003.

39. Chen, Y.; Zhu, X.; Loukopoulos, P.; Weston, L.A.; Albrecht, D.E.; Quinn, J.C. Genotypic identification of Panicum spp. in New South Wales, Australia using DNA barcoding. Sci. Rep. 2021, 11, 16055. [CrossRef] [PubMed]

40. Gurusinghe, S.; Latif, S.; Brown, W.B.; Weston, P.A.; Weston, L.A. A useful in vitro bioassay for evaluation of weed suppression by legume cover crop residues. In Proceedings of the 21st Australasian Weeds Society, Manly, Australia, 9-13 September 2018. 
41. Schwartz-Lazaro, L.M.; Copes, J.T. A Review of the Soil Seedbank from a Weed Scientists Perspective. Agronomy $2019,9,369$. [CrossRef]

42. Nikolić, N.; Loddo, D.; Masin, R. Effect of Crop Residues on Weed Emergence. Agronomy 2021, 11, 163. [CrossRef]

43. Weston, L.A.; Stanton, R.; Wu, H.; Mwendwa, J.; Weston, P.A.; Weidenhamer, J.; Brown, W.B. Comparison of grain crops and their associated residues for weed suppression in the southern Australian mixed farming zone. In Proceedings of the 19th Australasian Weeds Conference, Hobart, Australia, 1-4 September 2014; pp. 296-299.

44. Piltz, J.W.; Morris, S.G.; Weston, L.A. Winter Forage Crop Harvest Time Impacts Regeneration of the Annual Weeds Barley Grass, Annual Ryegrass and Wild Radish. Agronomy 2021, 11, 1700. [CrossRef] 